\title{
Feeding of Fin Whales (Balaenoptera physalus) off Iceland - Diurnal and Seasonal Variation and Possible Rates
}

\author{
Gísli A. Víkingsson \\ Programme for Whale Research, Marine Research Institute \\ P. O. Box 1390, 121 Reykjavík, Iceland
}

\begin{abstract}
Information on relative quantities of food remains found in fin whales (Balaenoptera physalus) caught off Iceland in 1967-89 are presented. In 1986-89 attempts were made to quantify these assessments in terms of weight and volumetric capacity of the stomachs. A forestomach visually assessed as full normally contained 5-600 kg of krill, the maximum being $760 \mathrm{~kg}$ in the present study $(n=34)$. The forestomach content was analysed in relation to seasonal and diurnal patterns in feeding activity. Daytime feeding rates declined with the progression of the season, especially in August-September. Pronounced diurnal fluctuations were found in the quantity of forestomach content peaking at 0000-0600 hr, but some feeding activity continued throughout the day. Diurnal variation of food remains found in different parts of the digestive tract suggested that the mean passage time from the forestomach to the fundic chamber was 3-6 hr, and that from the forestomach to the anus around 15-18 hr. The calculated daily feeding rates for fin whales in June-July were between 677 and $1356 \mathrm{~kg}$, assuming 6 and $3 \mathrm{hr}$ evacuation rates in the forestomach, respectively. The latter value fitted better with studies on seasonal fattening of fin whales off Iceland.
\end{abstract}

Key words: digestion rates, diurnal patterns, food/feeding, Iceland, whales

\section{Introduction}

Feeding behaviour of Balaenopterids is generally viewed as a discontinuous process, both seasonally and diurnally. The summer months are characterized by intense feeding at high latitudes, while feeding activity is much lower during winter. The degree of both seasonal and diurnal fluctuations seems, however, to vary somewhat between species and/or areas (Nemoto, 1957, 1959; Kawamura, 1970, 1974; Oshumi et al., 1970; Brodie, 1975; Oshumi, 1979; Lockyer, 1981; Best, 1982; Bushuev, 1986). Like other baleen whales the fin whale (Balaenoptera physalus) has a multi-chambered stomach system consisting of four compartments: the non-glandular forestomach, the main digestive stomach or fundic chamber, a connecting chamber (which is not considered a proper stomach chamber by some scientists) and the pyloric chamber (Hosokawa and Kamiya 1971, Gaskin 1978, Herwig et. al. 1984, Tarpley et. al. 1987, Olsen et. al. 1994). The forestomach has generally been regarded primarily as a chamber for mechanical grinding and temporary storage of large quantities of food (Slijper 1979, Gaskin 1978), but recent studies sug- gest that microbial digestion also takes place in this compartment (Herwig et al., 1984, Herwig and Staley 1986, Mathiesen et al., 1995).

Published data on feeding of the North-Atlantic fin whale have mostly been confined to analysis of the prey species, although unusual quantities are sometimes mentioned (Tomilin, 1967; Mitchell, 1975; Rörvik et al., 1976). Jonsgård (1966) gave some values on within-season variation in relative quantity of stomach contents in fin whales caught off Norway, and Lockyer (1986) described interseasonal variations in feeding activity of fin whales caught off Iceland.

Various attempts have been made to estimate the feeding rates of whales, using two main approaches. Firstly, feeding rates have been derived from studies on animals in captivity and/or from the observed or calculated (maximum) stomach fill (Nemoto, 1957; Klumov, 1963; Sergeant, 1969; Kawamura, 1974; Lockyer, 1981, 1987a; Bushuev, 1986; Innes et al., 1987; Horwood, 1987, 1990). In the second approach, feeding requirements are derived from calculated energy budgets, making as- 
sumptions about physiological parameters such as metabolic rates, and assimilation efficiency (Kawamura, 1975, Brodie, 1975; Lockyer, 1981, 1987a, 1987b; Armstrong and Siegfried, 1991, Markussen et al., 1992; Sigurjónsson and Víkingsson, 1997).

The fin whale is the most common large cetacean species in Icelandic and adjacent waters. According to a sightings survey conducted in the summer of 1995 the abundance in the East Greenland-Iceland stock area was around 19000 fin whales (NAMMCO Scientific Committee 1997). The species has been the primary target of the Icelandic post-war whaling operation, conducted from a single land station in Hvalfjördur, West Iceland (Sigurjónsson, 1988). The average annual catch between 1948 and 1985, was 234. In addition a total of 292 were sampled for scientific research during 1986-89.

On the whaling grounds west and southwest of Iceland, they fed predominantly on the euphausiid Meganyctiphanes norvegica (Rörvik et al., 1976). Crude quantitative assessments of stomach content have been made in connection with Icelandic whaling operations, on variable proportions of the catch during the period 1967-89. Since 1986, attempts have been made to quantify these assessments by weighing the stomach contents, measuring the volume capacity of the stomach and analysis of the content of the digestive tract. The present study brings together this information and feeding rates are discussed in relation to diurnal rhythm.

\section{Materials and Methods}

The material presented here is based on examination of fin whales caught within 200 naut. miles west and southwest of Iceland (Fig. 1) in the period 1967-89. Although some year to year fluctuations in catch positions occurred during the sampling period, the bulk of the animals were taken near the continental edge around the $1000 \mathrm{~m}$ depth contour throughout the period. The animals were landed 12-39 hr post mortem (mostly 20-25 hr) at the whaling station in Hvalfjördur, West Iceland, where the sampling and measurements were conducted. Within this period the sampling effort has been very variable (Table 1). In 1967, 1969, 1973 and 197782 data on stomach content were collected from variable proportions of the total catch, but from
1983 on the sampling has been nearly complete. Except for visual assessment of fore-stomach fill all the material presented in this paper is based on research on whales caught in 1986-89 as part of a special whale research program (Anon., 1986).

Prior to 1986 the observations were mostly confined to prey species composition and assessment of contents by eye into seven categories: 1: empty, 2:traces, 3: 1/4, 4: 1/2, 5: 3/4, 6: full, 7: not empty (quantitative information lacking). With respect to the long sampling period and possible personal variation in assessment of stomach content, the categories "half or more" $(4+5+6$ combined) and empty are considered most robust. From 1986 to 1989 the assessments of forestomach fill were continued in the same manner as in previous years for consistency. In addition, similar assessments were made of the content of the other stomach compartments and the intestines. Due to loss or damage of some foetuses and internal organs, the practice of slitting the belly of the whales at sea for cooling the meat was stopped in 1987 resulting in larger proportion of the whales landed with intact stomachs.

In 1988-89 attempts were made to quantify the visual assessments by weighing or measuring volumes of the content of stomachs previously assessed by eye. In the weighing process, the stomach content was put into a fine meshed sack, and after most of the liquid had been drained off, weighed on an electronic scale (the larger amounts), or a suspended balance (for contents less than $20 \mathrm{~kg}$ ). Usually there was very little or no liquid in the forestomach. However, in some cases the content was mixed with varying amounts of seawater. In measuring the volume of stomach contents, the food was placed into a porous rectangular metal container $(89 \times 78.5 \mathrm{~cm})$ and the volume calculated from the height of the content. The specific gravity of the stomach content was then calculated from the volume and weight of a small subsample (1-3 litres). In the few instances that the specific gravity was not determined, the mean value of all measurements $(0.93$ $\mathrm{g} / \mathrm{ml}$ ) was used.

In order to estimate the inner volume of fully expanded forestomachs, two methods were used. In 1986 forestomachs of fin whales were filled with water which was measured upon emptying. The general procedure was to tie the anterior end of the forestomach (at the junction between the forestomach and oesophagus) and use the posterior end 


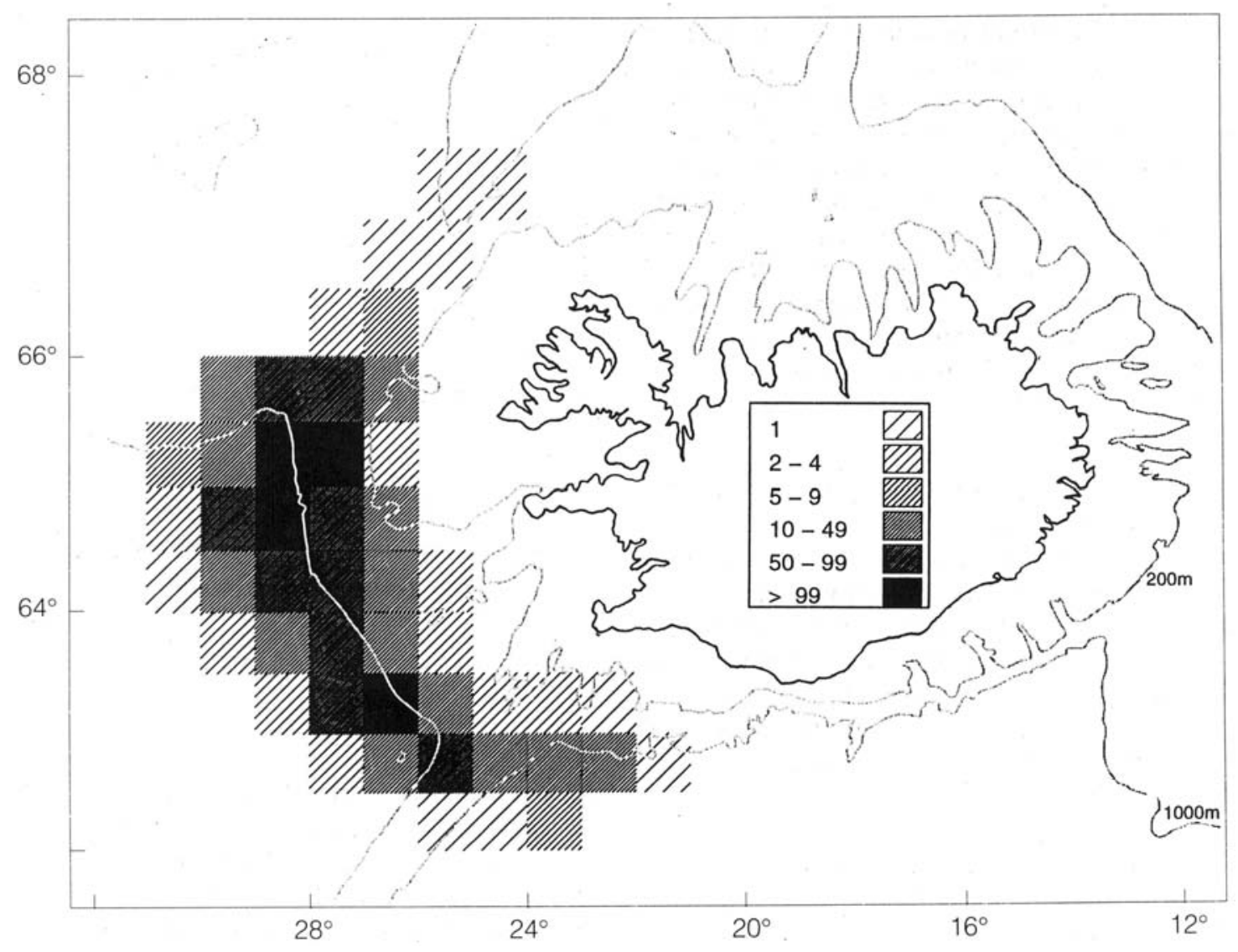

Fig. 1. Catch distribution of the fin whales analysed with respect to stomach contents during 1967-89.

TABLE 1. Number of fin whale stomachs examined in the study.

\begin{tabular}{lrrrcr}
\hline \hline Year & June & July & August & September & Total \\
\hline 1967 & & 54 & 13 & 2 & 69 \\
1969 & 15 & 71 & & & 86 \\
1972 & & 7 & & & 7 \\
1973 & & 46 & 34 & 9 & 89 \\
1977 & 13 & 36 & 23 & 18 & 90 \\
1978 & & 29 & 29 & 13 & 71 \\
1979 & 42 & 125 & 20 & 4 & 191 \\
1980 & 31 & 5 & 3 & 5 & 44 \\
1981 & 58 & 85 & 15 & & 158 \\
1982 & 5 & 55 & 16 & 1 & 77 \\
1983 & 33 & 54 & 12 & 2 & 101 \\
1984 & 67 & 67 & 21 & & 155 \\
1985 & 65 & 59 & 8 & & 132 \\
1986 & 19 & 28 & 3 & 9 & 59 \\
1987 & 31 & 44 & & & 75 \\
1988 & 12 & 37 & 9 & & 58 \\
1989 & 24 & 38 & & & 524 \\
Total & 422 & 833 & 206 & 63 & \\
\hline
\end{tabular}

(forestomach/fundic chamber junction) for filling and emptying of water, holding it at approximately $1 \mathrm{~m}$ height. Small holes were sewed to make the compartment waterproof. Similar methods were used when the posterior stomach compartments were measured in a single animal. Although only relatively intact stomach compartments were used in these experiments, this handling may have decreased the elasticity somewhat. In addition some attempts were made to estimate the volume of "naturally" gas extended forestomachs by outer measurements of three rectangular diameters, assuming a spherical shape. The estimated volume of an empty forestomach was then substracted for converting the outer-to inner volume. However, as the degree of expansion was only judged subjectively by eye, and the measurements taken opportunistically when stomachs appeared to be much extended, these measurements can only be regarded as minimum estimates of maximal expansion capacity. 
All identified food remains from fin whales caught in 1986-89 were euphausiid crustaceans. Samples of stomach content were taken during dissection of the whales, 1-3 hr after the whales were landed. Samples for prey species identification, and degree of digestion were taken from the forestomach, and fixed in $10 \%$ neutrally buffered formalin at the field laboratory. The degree of digestion of Euphausiids was determined by assigning each sample into one of the following categories (defined by Christina Lockyer, DIFRES Copenhagen; pers. comm.):

1. Firm and whole, almost fresh.

2. Softening of joints, some loss of meat and viscera from inside the body.

3. Loose body sections: carapace and meat absent, eyes often absent, telson often missing.

4. Carapace and eyes missing; forelegs and respiratory gills often present; tail segments with swimmerets totally or partly absent; no telson.

5. All chitin disappeared: only clear tail meat flesh in $10-15 \mathrm{~mm}$ lengths; few eyes separate.

6. Total "mush".

As the categories 1-2 were very rare they were pooled in the material presented here. Samples for chemical analysis were taken from all stomach chambers, and opportunistically from the various parts of the gut. All were frozen at $-20^{\circ} \mathrm{C}$ until the chemical analysis were made at the Agricultural Research Institute of Iceland. Water content was determined by weight loss through $48 \mathrm{hr}$ of freeze drying. The Kjeldahl method was applied in the total protein analysis, and total lipid content was determined by hydrolysis with $8 \mathrm{M} \mathrm{HCl}$. A more detailed description of these methods is given in Víkingsson (1990).

\section{Results}

\section{Difference between reproductive classes}

During June-July males more often had empty forestomachs than females (chi-square $=4.11$, d.f. $=1, p=0.04$ ) but the difference between the sexes was marginally insignificant considering the frequency of forestomachs estimated as halffull or more $(p=0.07)$. No significant difference was found in stomach content between pregnant females and females at other reproductive stages.

\section{Within-season variation}

Figure 2 shows the relationship between the date of catch and stomach fill (forestomach) for fin

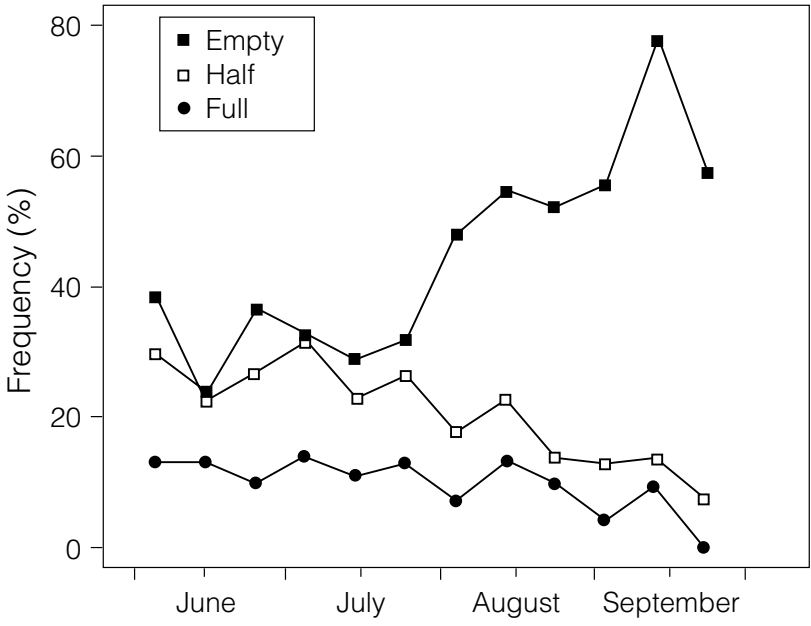

Fig. 2. Seasonal trend in stomach content of fin whales, caught between 0800 and $2000 \mathrm{hr}$ off Iceland. The figure gives frequencies of empty, full and "half-full or more" (half) forestomachs. The season is divided into ten- day intervals, starting 1 June.

whales caught in daylight hours (0800-2000 hr). The amount of stomach content clearly decreased throughout the season. This was most clearly demonstrated by the frequency of empty forestomachs (linear regression, $k$ (slope) $=0.39$, $F=33.33, p<0.001)$. The number of half full or more forestomachs also decreased significantly $(k$ $=-0.22, F=34.82, p<0.001)$, but the rate of decrease for full forestomachs was, although significant, much smaller $(k=-0.08, F=10.50, p<0.001)$. There seemed to be some kind of a breakpoint around 1 August, after which the contents of the forestomach decreased rapidly (Fig. 2).

\section{Diurnal variation in the forestomach}

In Fig. 3 forestomach fill is plotted against catch time, separately for the months June, July and August-September. Although the diurnal fluctuations seemed to be slightly more pronounced in June than in July (considering stomachs half-full or more), the overall pattern was similar in these two months with much lower levels in August-September, in accordance with Fig. 3. However, there seemed to be a sharp increase in stomach content in the evening (2100-2400 hr) during these late summer months and of the four whales caught before $0600 \mathrm{hr}$ during this period (not shown in Fig. $3 \mathrm{c}$ ), all contained some food and one had full forestomach. The diurnal fluctuations might thus be more pronounced in August-September than in June-July. Given the pattern shown in Fig. 3 a-c, it seems justifiable to pool data from animals caught 


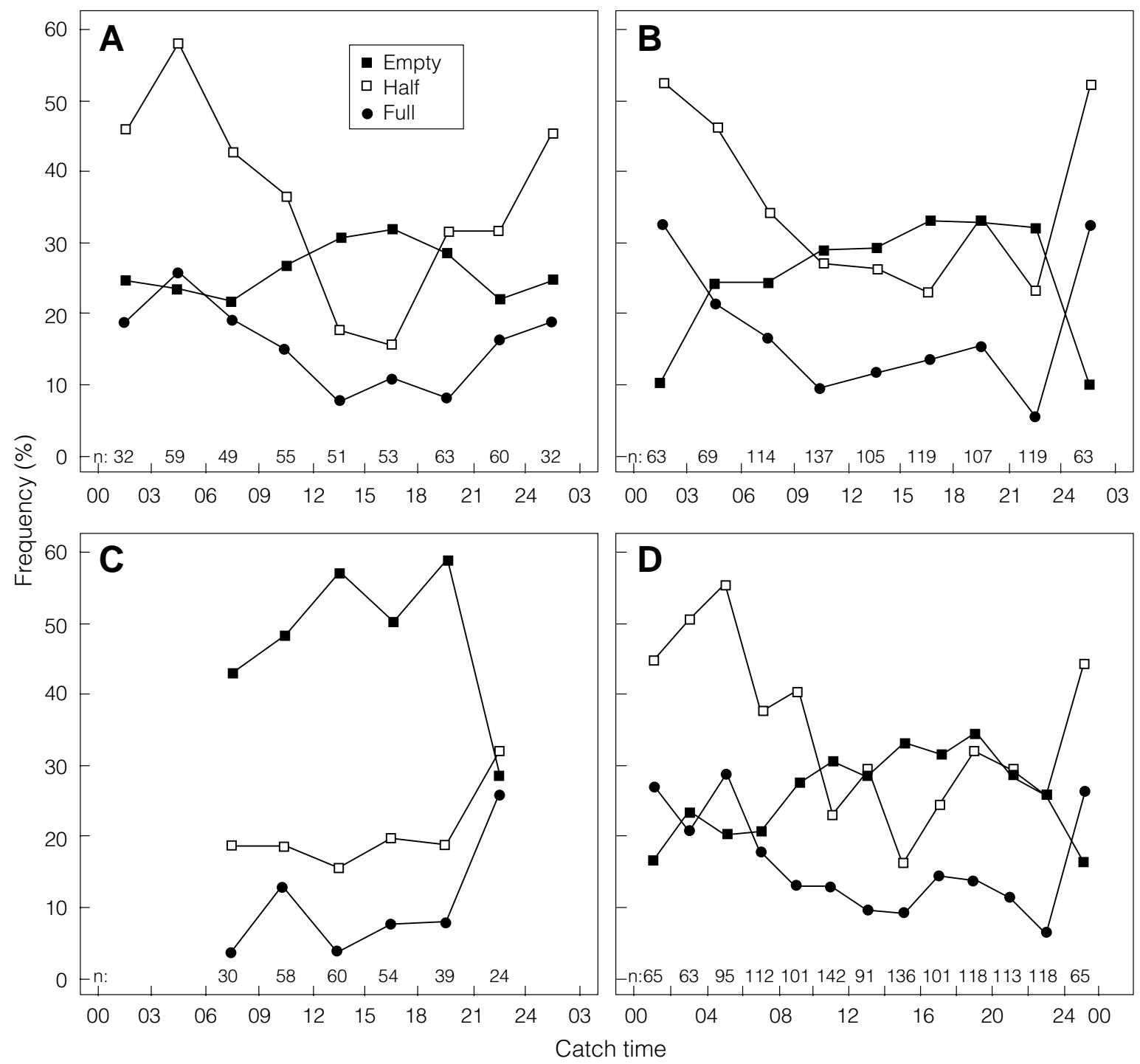

Fig. 3. Diurnal pattern in feeding activity of fin whales during June (A), July (B), August-September (C) and June-July combined (D). The frequencies are calculated for time intervals of three hr $(\mathbf{A}-\mathbf{C})$, or two hr (D). Iceland time is approximately $2 \mathrm{hr}$ off local sun time. Frequency categories as in Fig. 2.

in June and July, thereby increasing the sample size. In Fig. 3d this is done, and the forestomach fill is expressed as frequency per two-hour period in June-July.

Maximum forestomach content was found between midnight and $0600 \mathrm{hr}$. Within that period there was an increasing trend, reaching a peak in early morning between 0400 and $0600 \mathrm{hr}$. Thereafter the frequency of full or half full forestomachs declined gradually until a minimum was reached at 1200-1600 hr. During this period there was a corresponding increase in the number of empty forestomachs with a maximum frequency of 30$35 \%$. In the afternoon, the frequency of full or halffull forestomachs increased again, with peaks around 1700 and $1900 \mathrm{hr}$, respectively. However, feeding did not seem to be as intense during this afternoon peak as in the early morning feeding period when the frequency of full and half-full forestomachs was up to $29 \%$ and $56 \%$, respectively, compared to maximum frequencies of $15 \%$ full and $33 \%$ half-full during the latter period. It is also noteworthy that the frequency of empty forestomachs remained relatively high during the afternoon peak, but declined towards the evening. 


\section{Digestion rate}

In Fig. 4 classification categories of the content of the forestomach, the fundic chamber, the small intestines and rectum are plotted against catch time for fin whales caught in June-July in 198689. As very few animals were estimated to have half-full or more fundic chamber or rectum the classification category empty versus non-empty was considered the best indicator of digestive activity in these compartments. Although the sample size was small, some indications can be found regarding the passage time from the forestomach to anus. The frequency of non-empty fundic chambers was relatively high at around $70 \%$ at $0000-0900 \mathrm{hr}$, thereafter gradually decreasing to a minimum of $48 \%$ at $1200-1500 \mathrm{hr}$. In the afternoon the number of non-empty fundic chambers gradually increased to similar levels as during early morning. Diurnal variation in the content of the 3rd stomach chamber (not shown in Fig. 4) was similar to that of the fundic chamber. The content of the small intestines increased from early morning and reached a peak at $1200-1500 \mathrm{hr}$, thereafter decreasing. The frequency of non-empty rectal intestines was relatively constant at around 90\%, except at 1800-2400 hr when all examined rectal intestines contained some food remains (Fig. 4). The overall pattern of Fig. 4

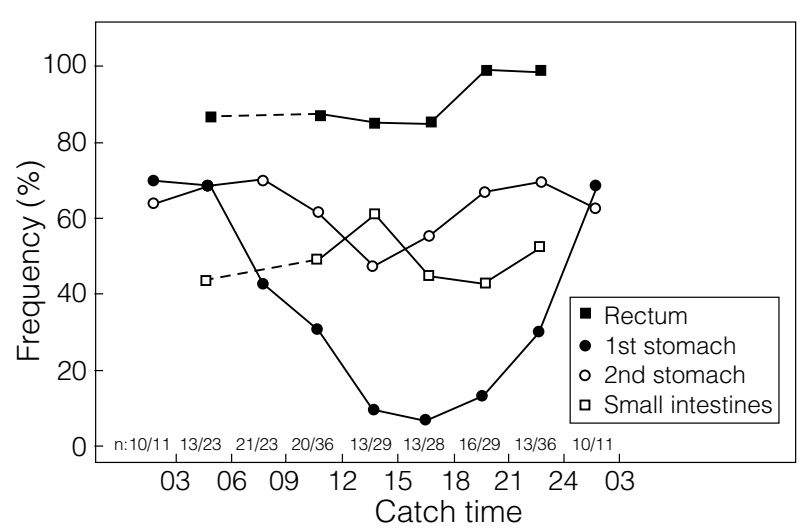

Fig. 4. Diurnal variation in the content of various parts of the digestive tract, expressed as frequencies in three hour periods. 1st Stomach: half-full or more forestomachs; 2nd stomach: non-empty fundic chambers; Small intestines: half-full or more small intestines; Rectum: non-empty rectum. Data from June-July 1986-89 are included. $\mathrm{n}$ : $\min / \max$ sample size: number of observations of intestines and rectum/forestomachs. Data were pooled for the period 0000-0900 hr where observations within a three-hour period were fewer than 10 (small intestines and rectum). indicates that the peak at $0000-0600 \mathrm{hr}$ in the forestomach corresponded to the peak at 0300-0900 $\mathrm{hr}$ in the fundic chamber, leading to a maximum at $1200-1500 \mathrm{hr}$ in the small intestines, followed by the peak at $1800-2100 \mathrm{hr}$ in the rectum. According to this small sample the mean passage time from the forestomach to the fundic chamber was 3-6 hr, and that to the anus would then be around 15-18 hr.

In Fig. 5 the state of digestion of the forestomach content is shown in relation to catch time. The frequency of fresh stomach content was clearly highest in the early morning hours (0300-0600 hr), and again there seemed to be a smaller peak in the evening. Very digested food was most often found in whales caught during mid-day (1200-1800 hr), and shortly after midnight $(0000-0300 \mathrm{hr})$.

Table 2 gives the results of the chemical analysis of stomach and intestine contents. The percentage of dry material was highest in the first two stomach compartments, which was in agreement with visual observations.

The percentage dry material was lowest in the mid-intestines, increasing again in the rectum. Protein, lipid and consequently the energetic content of the digestive tract seemed to decrease from anterior to posterior (Table 2). However, except for the rectal region this decrease was not evident if the values were expressed as percentages of dry weight.

\section{Stomach volume capacity}

The relationship between maximum forestomach content and length of fin whales was examined using linear regression of $\log$ transformed data on weight of the contents of forestomachs that had previously been assessed as full, $3 / 4$ full or half-full (in the latter two cases the weight was multiplied by $11 / 3$ and 2 respectively):

$$
\begin{gathered}
S=0.47 L^{2.36} \\
F(1,21)=7.07 ; p=0.01
\end{gathered}
$$

where $S$ is maximum forestomach content ( $\mathrm{kgs})$, and $L$ is length $(\mathrm{m})$.

Table 3 gives the volumes of water-filled forestomachs from fin whales, $16.52-19.65 \mathrm{~m}$ at length. Also shown are volumes of the other three stomach compartments of a single immature female fin whale. The "krill carrying capacity" of the stom- 


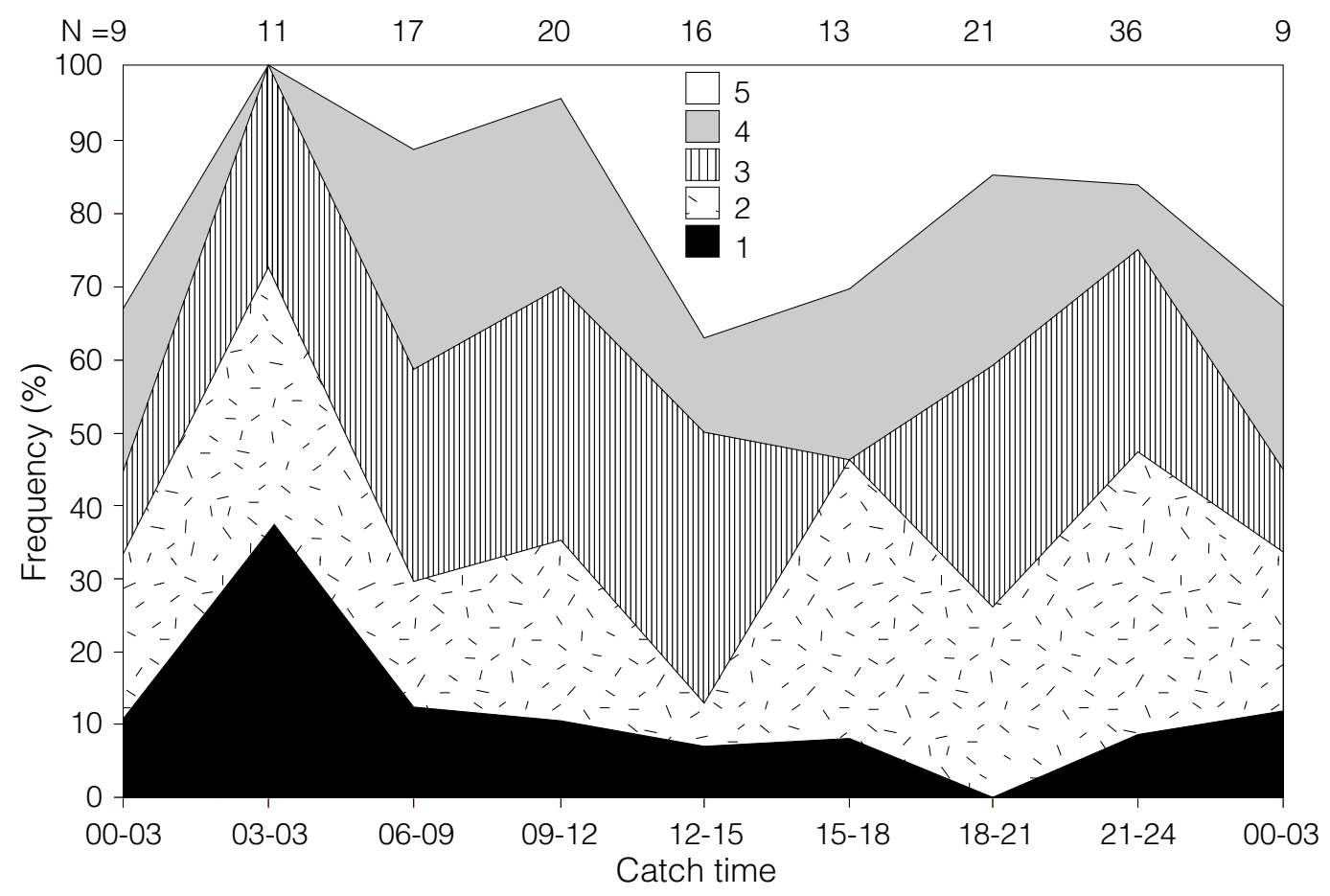

Fig. 5. Diurnal variation in relative freshness of krill (Meganyctiphanes norvegica) from the forestomachs of fin whales caught off Iceland in 1986-89. The data is expressed as cumulative frequency in five stages of increasing digestion from bottom to top in the figure.

TABLE 2. Chemical analysis of the content of various parts of the digestive tract. Values are expressed as percentages of wet weight ( $\mathrm{SD}$ in parenthesis). Energy $(\mathrm{KJ})$ is calculated as $22.4 \mathrm{KJ} / \mathrm{g}$ protein and $39.5 \mathrm{KJ} / \mathrm{g}$ lipid.

\begin{tabular}{lrccccc}
\hline \hline Sampling site & $\mathrm{n}$ & Dry & Ash & Protein & Lipid & Energy \\
\hline Forestomach & 31 & $19.11(4.37)$ & $3.31(0.73)$ & $12.14(2.83)$ & $4.15(2.89)$ & $4.36(1.48)$ \\
Fundic chamber & 5 & $18.16(5.26)$ & $3.47(0.79)$ & $10.60(2.62)$ & $3.44(1.74)$ & $3.73(1.24)$ \\
Pyloric chamber & 9 & $12.29(6.30)$ & $2.08(1.42)$ & $6.97(3.01)$ & $3.29(3.11)$ & $2.86(1.55)$ \\
Duodenal ampulla & 1 & 10.52 & 2.07 & 8.74 & 1.79 & 2.67 \\
Anterior small intestines & 1 & 12.28 & 1.28 & 6.66 & 2.92 & 2.65 \\
Mid small intestines & 3 & $7.35(1.41)$ & $2.45(1.36)$ & $4.23(0.58)$ & $1.61(0.41)$ & $1.58(0.12)$ \\
Rectum & 1 & 13.43 & 5.03 & 4.02 & 1.44 & 1.47 \\
\hline
\end{tabular}

TABLE 3. Estimates of stomach volumetric capacity of fin whales. The values were derived by filling the stomach chambers with water. The "krill carrying capacity" was calculated from the measured volume assuming a specific gravity of $0.93 \mathrm{~g} / \mathrm{ml}$.

\begin{tabular}{|c|c|c|c|c|}
\hline Serial number & Length $(\mathrm{m})$ & Stomach chamber & Volume (1) & Krill weight (kgs) \\
\hline 88012 & 16.52 & Forestomach & 443 & 412 \\
\hline 86032 & 17.7 & Forestomach & 544 & 506 \\
\hline 86032 & 17.7 & Fundic chamber & 132 & 123 \\
\hline 86032 & 17.7 & Pyloric chamber + Duodenal ampulla & 164 & 153 \\
\hline 86031 & 18.9 & Forestomach & 430 & 400 \\
\hline 86039 & 18.9 & Forestomach & 444 & 413 \\
\hline 86028 & 19.65 & Forestomach & 450 & 418 \\
\hline
\end{tabular}


ach was calculated by multiplying the volume with the mean specific gravity of krill in the forestomach as measured at the field laboratory $(0.93 \mathrm{~kg} / \mathrm{l})$. The handling of the stomach compartments prior to filling them with water (sewing and/or tying holes and junctions) has probably resulted in some underestimation of their inner volume. Hence, the values obtained were somewhat lower than maximum observed stomach content from whales of similar lengths.

The results from the outer measurements of gas expanded forestomachs were highly variable for similarily sized whales. This was probably due to the variable, and uncontrolled gas pressure. However, the highest values may indicate the lower limits of the expansion capabilities. In five fin whales, $18.29-18.85 \mathrm{~m}$ at length $($ mean $=18.45 \mathrm{~m})$, with apparently fully inflated forestomachs, the mean inner volume was calculated as 754 litres (range: 492-1 095).

Table 4 gives the actual weight of forestomach contents in relation to the visual assessment of stomach fill. Also given are predicted values, calculated from the equation, for a $18.6 \mathrm{~m}$ fin whale. The low value for the category " $1 / 4$ full" indicated that there has been a tendency to assess relatively little content as 1/4 full rather than traces. Unfortunately very few animals with more than half-full forestomachs were landed after these measurements were started, but the mean values seemed reasonable compared to those assessed as halffull (Table 4).

\section{Feeding rate}

According to Fig. 4 the food passes from the forestomach to the fundic chamber in 3-6 hr. An indication of the daily consumption can then be obtained from the frequencies of forestomach fill, multiplied by the weight values given in Table 4 , adding up consecutive three or six hourly periods. The results for June-July are given in Table 5. Such calculations are impossible for the period AugustSeptember due to the halt of whaling operations during the night and early morning. The calculated values for mean forestomach content within each time-interval are very similar whether the data from actual weighings of stomach content (Table 4) or the data from the equation for a medium sized whale are used (Table 5). The difference in the daily consumption between these two methods was only 4-5 $\mathrm{kg}$. Sticking to the first method, the mean daily consumption was between 677 and $1356 \mathrm{~kg}$ depending on the assumed passage time from the first to the second stomach chamber. Judging from Fig. 4, the latter value would appear more likely.

\section{Discussion}

Apart from the difference between the sexes in the relative frequency of empty forestomachs, no significant differences were found between reproductive classes. Hence, the difference in seasonal fattening between reproductive classes (Lockyer, 1986, Víkingsson, 1990) is not reflected in the amount of forestomach content according to this relatively simple approach. Segregation of reproductive classes (Rørvik et al., 1976, Martin, 1982) may, therefore, contribute more to the difference in energetic condition than feeding rates on a daily basis. The relationship between stomach content and reproductive status needs, however, more detailed analysis.

The amount, and state of digestion of food remains reveal a clear diurnal variation in feeding

TABLE 4. Mean weight ( $\mathrm{kg}$ ) of contents of stomachs, for which the fullness had previously been assessed visually. Also, given are calculated values, based on the equation (see text) for a medium-sized fin whale (18.6 m).

\begin{tabular}{|c|c|c|c|c|}
\hline \multirow{2}{*}{$\begin{array}{c}\text { Visual } \\
\text { assessment }\end{array}$} & \multirow[b]{2}{*}{$\mathrm{n}$} & \multicolumn{2}{|c|}{$\begin{array}{l}\text { Stomach content }(\mathrm{kg}) \\
\text { Measured }\end{array}$} & \multirow[b]{2}{*}{ Calculated } \\
\hline & & mean & range & \\
\hline Traces & 7 & 32.9 & $0.15-50.0$ & \\
\hline $1 / 4$ & 10 & 77.4 & $52.0-100.7$ & 117 \\
\hline $1 / 2$ & 12 & 204.4 & $113.0-317.2$ & 233 \\
\hline $3 / 4$ & 3 & 342.2 & $282.6-375.5$ & 350 \\
\hline $4 / 4$ & 2 & 562.3 & $364.8-759.8$ & 466 \\
\hline
\end{tabular}


TABLE 5. Mean stomach content of fin whales in different time intervals. The values are calculated from the conversion factors given in Table 4 (WT1), or from the estimated proportion of a full stomach (466 kg according to the equation in text (WT2). A. The total value assumes a mean passage time of $3 \mathrm{hr}$ between the the first two stomach chambers. B. The corresponding passage time is assumed $6 \mathrm{hr}$.

\begin{tabular}{|c|c|c|c|}
\hline \multirow[b]{2}{*}{ Time } & \multicolumn{3}{|c|}{ Mean stomach content $(\mathrm{kg})$} \\
\hline & $\mathrm{n}$ & WT1 & WT2 \\
\hline \multicolumn{4}{|c|}{ A } \\
\hline $0-3$ & 95 & 238.0 & 223.7 \\
\hline $3-6$ & 128 & 234.3 & 223.0 \\
\hline $6-9$ & 163 & 180.6 & 177.2 \\
\hline $9-12$ & 192 & 151.3 & 153.4 \\
\hline $12-15$ & 156 & 125.1 & 127.8 \\
\hline $15-18$ & 172 & 132.6 & 132.9 \\
\hline $18-21$ & 170 & 154.8 & 152.4 \\
\hline $21-24$ & 179 & 140.0 & 142.7 \\
\hline Total & 1255 & 1356.7 & 1333.1 \\
\hline \multicolumn{4}{|c|}{ B } \\
\hline $0-6$ & 223 & 235.7 & 223.1 \\
\hline $6-12$ & 355 & 164.9 & 164.4 \\
\hline $12-18$ & 328 & 128.9 & 130.4 \\
\hline $18-24$ & 349 & 147.6 & 149.2 \\
\hline Total & 1255 & 677.1 & 667.1 \\
\hline
\end{tabular}

activity of fin whales feeding on planktonic Crustacea west and southwest of Iceland. Similar diurnal fluctuations have been found in a number of earlier studies on balaenopterids from different areas. Nemoto $(1957,1959)$ found two peaks (morning and afternoon) of feeding activity in North $\mathrm{Pa}$ cific blue (Balaenoptera musculus), fin and sei (Balaenoptera borealis) whales, and a similar pattern in Southern Hemisphere fin whales. There were however considerable variations depending on locality, time of the season and prey species. Kawamura (1970) also found highest incidence of feeding in the morning, but no distinct recovery in the evening in Southern Hemisphere sei whales. Similar pattern was found for Antarctic minke whales (Balaenoptera acutorostrata) (Ohsumi, 1979; Bushuev, 1986). Due to darkness, few of these studies reported on data for the period 0000-0300 hr. According to the present study this is part of a period when maximum feeding activity occurs, lasting from around midnight to $0600 \mathrm{hr}$. Nemoto's (1957) data also show maximum feeding rates at
$0000-0400 \mathrm{hr}$ in the early and mid-summer in the Antarctic. In addition to the early morning peak, we also found a smaller afternoon peak at 1800$2000 \mathrm{hr}$ in July (Fig. 3b).

Despite the pronounced diurnal fluctuations in feeding activity, some feeding seems to take place at all times of the day. Although full stomachs are rarely encountered in whales caught in mid-day, they do occur, and fresh krill has been found, albeit at low frequency, in the stomachs of whales caught throughout the day (Fig. 5). Lockyer (1981), in reviewing the diurnal feeding pattern of baleen whales concluded, that whilst feeding activity may take place at all times, feeding generally reaches a peak once or perhaps twice a day. The present data agree with that conclusion.

The observed diurnal variation in feeding activity may be related to the known diurnal vertical migration of the main prey species (Mauchline, 1980, H. Vilhjálmsson, (Marine Research Institute, Reykjavik, Iceland, pers. comm.)). According to this study, fin whales appear to feed most successfully when the planktonic crustaceans stay in the uppermost layers of the water column during the night. Most studies on diving behaviour of fin whales have indicated longer, and presumably deeper, dives during day than during night (Watkins et al., 1981, 1984; Stone et al., 1992). Although this period of short dives has often been interpreted as a resting phase, it may also indicate surface feeding activity (Kopelman and Sadove, 1995). Some authors have noted an apparent resting or sleeping period during the night from observations of individual baleen whales (Watkins et al., 1981, Folkow and Blix, 1993). The apparent drop in the frequency of full stomachs coinciding with similarly sized increase in the frequencies of half-full and empty stomachs (Fig. 3d) and increase in digestion (Fig. $5)$ might indicate some paucity in feeding activity in the middle of the night.

The chemical composition of the contents of the forestomach is similar to published values for intact krill (Heyerdahl, 1932; Raymont et al., 1971; Mauchline and Fisher, 1969). Thus, the microbial fermentation in the fin whale forestomach, as suggested by Herwig and Staley (1986), apparently does not affect the total lipid, protein and ash concentrations. The relatively high percentages of ash and dry material in the rectum could indicate some absorption of water in the posterior part of the digestive tract. 
The estimates of forestomach volume capacity obtained by filling the compartment with water (Table 3), are within the range of values for amounts of krill observed in forestomachs assessed as full (Table 4). They did not, however, reach the maximum recorded amounts for fin whales of similar size, possibly because of reduced elasticity due to the handling of the stomach. The assessments of forestomach volume based on external measurements of apparently fully gas expanded stomachs are concurrent with earlier measurements (Lockyer, 1987a), where inner volumes of 450 and 1200 litre were found for 17.1 and $19.2 \mathrm{~m}$ fin whales, respectively. The highest values based on outer measurements of gas expanded forestomachs may be influenced by post mortem changes in the elasticity of the stomach wall (Gaskin, 1982). However, the observations of stomach content of around $750 \mathrm{~kg}$ in 17.5-18.5 m fin whales show that the forestomach can distend considerably more, and corresponds to the amount normally found in an apparently full stomach. Also as a general rule, the quantities recovered from the stomach must be considered minimal values, as most, if not all potential biasing factors, tend to bias the estimates downwards (vomiting, disturbance of feeding behaviour due to chasing, effect of the harpoon explosion, post mortem "digestion"). In fact analysis of the data showed a significant negative correlation between the stomach content and both chasing duration $(F=19.78$, $p<0.01)$ and post mortem times $(F=31.43$, $p<0.001)$.

According to the single measurement of the volume of all stomach chambers (Table 3), the forestomach constitutes a larger part of the total stomach volume than found in bowhead whales (Balaena mysticetus) (Tarpley et al., 1987), but similar to that found in large minke whales (Olsen et al., 1994). This may be related to the more continuous "skimming" feeding method (Nemoto, 1959, 1970) of bowheads, as compared to the "swallowing" method of fin and minke whales.

The most critical factor in the calculations of daily consumption rates is the assumed passage time from the first to the second stomach chamber. The compartmentalization of the cetacean stomach is generally viewed as an adaptation to opportunistic feeding, and discontinuous distribution of prey species in time and space. The cellular division of labour, the increased surface area and microbial digestion promote rapid digestion and, together with great distensibility of the forestomach, allow the animals to take maximum advantage of food, when encountered (Gaskin, 1978, Olsen et al., 1994, Mathiesen et al., 1995). Digestion rates have been found to be high in odontocete cetacea (Sergeant, 1962; Tomilin, 1967; Ridgway, 1972). Using X-ray techniques, Ridgway (1972) found that in Tursiops truncatus material injected by a stomach tube reaches the anus in 1-3 hr. He noted that in this species the majority of feces is usually passed in the first six hours after feeding. The mean passage time of food for captive belugas (Delphinapterus leucas) has been estimated as 4-5 hr (Kastelein et al., 1994). Tomilin (1967) estimated the passage time for a full meal to reach the large intestine as $14 \mathrm{hr}$ in the common dolphin (Delphinus delphis). The estimate of digestion rate from the present study, although suffering from small sample sizes, is within the range of values given for captive odontocetes. Thus, the approximately $15 \mathrm{hr}$ passage time from the forestomach to the rectum (Fig. 4), agrees well with Tomilin's (1967) estimate, although most of the other studies have yielded somewhat higher digestive rates (Ridgway, 1972; Kastelein et al., 1994). As shown in Fig. 4 the frequency of empty fundic chambers begins to increase approximately $3 \mathrm{hr}$ after a sharp drop in the frequency of half-full or more forestomachs during the morning. At the same time there is an increase in the content of the intestines, reaching a peak around $9 \mathrm{hr}$ after the peak in the forestomach (having in the meantime passed through the three digestive stomach compartments). Therefore, of the two values used to calculate the feeding rate (Table 5), 3 $\mathrm{hr}$ passage time appears more likely and hence a mean consumption rate of $1357 \mathrm{~kg} /$ day in June-July.

Using the weight-length formula of Víkingsson et al. (1988) on a medium-sized fin whale $(18.6 \mathrm{~m})$ the values for daily consumption (Table 5) amounted to $1.6-3.3 \%$ of body weight. Various published values are available for feeding rates of cetaceans. Klumov (1963) and Sergeant (1969) calculated rates of 3-4\% of body weight per day (bw/d) for large whales. Gaskin, (1982) considered 2.5$3 \% \mathrm{bw} / \mathrm{d}$ as the most realistic values for rorquals, and Lockyer (1981) concluded that the average value throughout the year was around $1.2 \% \mathrm{bw} / \mathrm{d}$. The latter distinguished between an intense feeding period of around 120 days during the summer, when feeding rates were around $3-4 \% \mathrm{bw} / \mathrm{d}$, and a reduced winter feeding at about a tenth of summer amounts. In a later study on North Atlantic fin 
whales, she found summer feeding rates of $4 \% \mathrm{bw} / \mathrm{d}$ to conform with data on seasonal fattening for pregnant females (Lockyer, 1987a, 1987b). In a similar study based on carcass analysis of fin whales off Iceland Víkingsson (1995) found minimum feeding rates to vary from $1.8 \% \mathrm{bw} / \mathrm{d}$ for immatures to $2.5 \% \mathrm{bw} / \mathrm{d}$ for pregnant females. These studies indicate feeding rates of more than one maximally expanded stomach fill per day (Table 4). Horwood $(1987,1990)$ has argued that even $1.2 \%$ bw/d may be too high for sei and minke whales. His calculations assumed a maximum of one stomach fill per day and $20 \%$ of the sei whales not feeding on any one day. Despite pronounced diurnal variation in feeding activity, the present data indicate some feeding activity throughout the day. This, together with the digestion rates indicated above, suggest that the feeding activity should be viewed as a semicontinuous process rather than one or two distinct meals per day. This is supported by behavioural studies on minke whales (Lynas and Sylvestre, 1988), a species also known to show pronounced diurnal variation in stomach content (Oshumi, 1979; Bushuev, 1986). Minke whales were found to spend approximately $61 \%$ of its time during daylight hours feeding, and a further $36 \%$ in related activities during summer (Lynas and Sylvestre, 1988).

Of the two alternative assumptions on digestive rates given in Table 5, $3 \mathrm{hr}$ mean passage time from the 1 st to the 2 nd stomach chamber fits better with the energetic studies given above. The digestion process however needs further study. A longer feeding period than 120 days does not seem unlikely in the Northern Hemisphere (Brodie, 1975), especially for immatures (Víkingsson, 1995).

In August-September the lack of data from the dark hours prevents corresponding calculations, but if the same proportions of daytime versus night-time feeding as in June-July are assumed, feeding rates would be considerably lower during these months than earlier in the summer (Figs 2-3). Such reduced feeding rates during late summer/autumn are, however, inconsistent with data on seasonal fattening, which show unreduced rates of energy deposition throughout this period (Lockyer, 1987a, 1987b; Víkingsson, 1990, 1995). The sharp increase in the frequency of full and half-full stomachs in the evening (Fig. 3c), together with the stomach contents of the few whales caught before $0600 \mathrm{hr}$ in August-September could indicate that the diurnal fluctuations are more pronounced in late summer and autumn. The observed reduction in daytime feeding rates (Fig. 2) may therefore be compensated by increased feeding activity during night.

\section{Acknowledgements}

The sampling was initiated by the Sea Mammal Research Unit (SMRU) (formerly the Whale Research Unit), Cambridge, and later taken over by the Marine Research Institute, Reykjvík (MRI). The persons responsible for organizing and carrying out this sampling are sincerely thanked, in particular Sidney G. Brown, Christina Lockyer and Antony Martin of the SMRU and Jóhann Sigurjónsson of the MRI. Special thanks are extended to Kristján Loftsson director of Hvalur H. F. and all the staff at the whaling station for their cooperation during the sampling and measuring process. In particular, I thank Oddur Ingólfsson, Sveinn Bragason, Magnús Ástvaldsson, Átli Konrádsson, Árni Alfredsson and Sverrir D. Halldórsson, all of the MRI, for their sampling work, the last named also for laboratory work and drawings. Jóhann Sigurjónsson is thanked for useful suggestions during the preparation of the manuscript. Special thanks to Arngrímur Thorlacius of the Agricultural Research Institute for conducting the chemical analysis.

\section{References}

ANON. 1986. Whale research in 1986-1989 - an outline of programme and budget. Hafranns Ûknarstofnunin, Reykjavík, May 1986. 1st revision. 38 p.

ARMSTRONG, A. J., and W. R. SIEGFRIED. 1991. Consumption of Antarctic krill by minke whales. Antarctic Sci., 3(1): 13-18.

BEST, P. B. 1982. Seasonal abundance, feeding, reproduction, age and growth in minke whales off Durban. Rep. Int. Whal. Comm., 32: 759-86.

BRODIE, P. F. 1975. Cetacean energetics, an overview of intraspecific size variation. Ecology, 56: 152-61.

BUSHUEV, S. G. 1986. Feeding of minke whales, Balaenoptera acutorostrata, in the Antarctic. Rep. Int. Whal. Comm., 36: 241-5.

FOLKOW, L. P., and A. S. BLIX. 1993. Daily changes in surfacing rates of minke whales (Balaenoptera acutorostrata) in Norwegian waters. Rep. Int. Whal. Comm., 43: 311-314.

GASKIN, D. E. 1978. Form and function in the digestive tract and associated organs in Cetacea, with a consideration of metabolic rates and specific energy budgets. Oceanogr. Mar. Biol. Annu. Rev., 16: 313-45.

GASKIN, D. E. 1982. The Ecology of Whales and 
Dolphins. Heinemann. London 459 p.

HERWIG, R. P. and J. P. STALEY. 1986. Anaerobic bacteria from the digestive tract of North Atlantic fin whales (Balaenoptera physalus). FEMS Microbiol. Ecol., 38: 361-371.

HERWIG, R. P., J. T. STALEY, M. K. NERINI, and H. W. BRAHAM. 1984. Baleen whales: Preliminary evidence for forestomach microbial fermentation. Appl. Environ. Microbiol., 47(2): 421-423.

HEYERDAHL, E. F. 1932. Hvalindustrien. I: Ramaterialet. Kommandor Chr. Christensen Hvalfangstmuseum, Sandefjord, Publ. No. 7, 160 p.

HORWOOD, J. 1987. The Sei Whale. Population Biology, Ecology \& Management. CROOM HELM, London, New York, Sydney. 375 p.

HORWOOD, J. 1990. Biology and Exploitation of the Minke Whale. CRC Press, Florida, 238 p.

HOSOKAWA, H., and T. KAMIYA. 1971. Some observations on the cetacean stomachs, with special considerations on the feeding of whales. Sci. Rep. Whales Res. Inst., 23: 91-101.

INNES, S., D. M. LAVIGNE, W. M. EARLE, and K. M. KOVACS. 1987. Feeding rates of seals and whales. J. of Anim. Ecol., 56: 115-30.

JONSGÅR, A. 1966. Biology of the North Atlantic fin whale Balaenoptera physalus. Taxonomy, distribution, migration and food. Hvalrådets skrifter, 49: $1-62$.

KASTELEIN, R. A., J. FORD, E. BERGHOUT, P. R. WIEPKEMA and M. VAN BOXSEL. 1994. Food consumption, growth and reproduction of Belugas (Delphinapterus leucas) in human care. Aq. Mam., 20(2): 81-97.

KAWAMURA, A. 1970. Food of sei whales taken by Japanese whaling expeditions in the Antarctic season 1967/68. Sci. Rep. Whales Res. Inst., Tokyo, 22: 127-152.

KAWAMURA, A. 1974. Food and feeding ecology in the southern sei whale. Sci. Rep. Whales Res. Inst., Tokyo, 26: 25-144.

KAWAMURA, A. 1975. A consideration of an available source of energy and its cost for locomotion in fin whales with special reference to the seasonal migrations. Sci. Rep. Whales Res. Inst., Tokyo, 27: 61-79.

KLUMOV, S. K. 1963. Feeding and helminth fauna of whalebone whales /Mystacoceti) in the main whaling grounds of the world ocean. Tr. Inst. Okeanol., 71: 94-194.

KOPELMAN, A. H., and S. S. SADOVE. 1995. Ventilatory rate differences between surface-feeding and non-surface-feeding fin whales (Balaenoptera physalus) in the waters off Eastern Long Island, New York, U.S.A., 1981-1987. Mar. Mam. Sci., 11(2): 200-208.

LOCKYER, C. 1981. Growth and energy budgets of large baleen whales from the Southern Hemisphere. FAO Fish. Ser. (5) (Mammals in the Seas), 3: 379-487.

LOCKYER, C. 1985. Body fat condition in Northeast Atlantic fin whales, Balaenoptera physalus, and its relationship with reproduction and food resource.
Can. J. Fish. Aquat. Sci., 43: 142-7.

LOCKYER, C. 1987a. Evaluation of the role of fat reserves in relation to the ecology of North Atlantic fin and sei whales. In: Approaches to Marine Mammal Energetics. A. C. Huntley, D. P. Costa, G. A. J. Worthy, and M.A. Castellini (eds.), Society for Marine Mammalogy, Special Publication No. 1, p. 183-203.

LOCKYER, C. 1987b. The relationship between body fat, food resource and reproductive energy costs in North Atlantic fin whales. Symp. Zool. Soc. Lond., 57: 343-361.

LYNAS, E. M., and J. P. SYLVESTRE. 1988. Feeding teqniques and foraging strategies of minke whales (Balaenoptera acutorostrata) in the St. Lawrence Estuary. Aq. Mam., 14(1): 21-32.

MARKUSSEN, N. H., M. RYG, and C. LYDERSEN. 1993. Food consumption of the NE Atlantic minke whale (Balaenoptera acutorostrata) population estimated with a simulation model. ICES J. Mar. Sci., 49: 319-323.

MARTIN, A. R. 1982. Influence of date and position of capture on the length of fin whales taken by Iceland. Rep. Int. Whal. Comm., 32: 331-334.

MATHIESEN, S. D., T. H. AAGNES, W. SØRMO, E. S. NORDØY, and A. S. BLIX. 1995. Digestive physiology of minke whales. In: Whales, seals, fish and man, A. Schytte Blix, L. Wallöe, and Ö. Ulltang (eds.), Elsevier Science B.V., 720 p.

MAUCHLINE, J. 1980. The biology of euphausiids. $A d v$. Mar. Biol., 18: 371-595.

MAUCHLINE, J., and L. R. FISCHER. 1969. The biology of euphausiids. Adv. Mar. Biol., 7: 1-454.

MITCHELL, E. 1975. Trophic relationships and competition for food in Northwest Atlantic whales. Proceedings of the Canadian Society of Zoologists Annual Meeting, p. 123-133.

NAMMCO Scientific Committee, 1997. Report of the Fifth Meeting, Tromsø, Norway 10-14 March 1997. North Atlantic Marine Mammal Commission (NAMMCO/7/6).

NEMOTO, T. 1957. Foods of baleen whales in the Northern Pacific. Sci. Rep. Whales Res. Inst., Tokyo, 12: 33-39.

NEMOTO, T. 1959. Food of baleen whales with reference to whale movements. Sci. Rep. Whales Res. Inst., Tokyo, 14: 149-290.

NEMOTO, T. 1970. Feeding pattern of baleen whales in the ocean. In: Marine Food Chain. J. H. Steele (ed.) Oliver and Boyd, Edinburgh, p. 241-52.

OHSUMI, S. 1979. Feeding habits of the minke whale in the Antarctic. Rep. Int. Whal. Comm., 29: 473-476.

OHSUMI, S., Y. MASAKI, and A. KAWAMURA. 1970. Stock of the Antarctic minke whale. Sci. Rep. Whales Res. Inst., Tokyo, 22: 75-126.

OLSEN, M. A., E. S. NORDÖY, A. S. BLIX, and S. D. MATHIESEN. 1994. Functional anatomy of the gastrointestinal system of northeastern Atlantic minke whales (Balaenoptera acutorostrata). J. Zool., 234(1): 55-74. 
RAYMONT, J. E. G., R. T. SRINISVASAGAN, and J. K. B. RAYMONT. 1971. Biochemical studies on marine zooplankton. 8. Further investigations on Meganyctiphanes norvegica (M.Sars). Deep-Sea Res. 18(12): 1167-1178.

RIDGWAY, S. H. 1972. Homeostasis in the aquatic environment. In: Mammals of the Sea: Biology and Medicine. S.H. Ridgway (ed). Charles C. Thomas, Springfiels, Illinois, p. 590-747.

RÖRVIK, C. J., J. JÓNSSON, O. A. MATHISEN, and A. JONSGARD. 1976. Fin whales, Balaenoptera physalus (L.), off the west coast of Iceland. Distribution, segregation by length and exploitation. Rit Fiskideildar, 5: 1-30.

SERGEANT, D. E. 1962. The biology of the pilot or pothead whale Globicephala melaena (Traill) in Newfoundland waters. Bull. Fish. Res. Board Can., 132: $1-84$.

SERGEANT, D. E. 1969. Feeding rates of Cetacea. Fiskeridir. Skr. Havunders., 15: 246-258.

SIGURJÓNSSON, J. 1988. Operational factors of the Icelandic large whale fishery. Rep. Int. Whal. Comm., 38: $327-333$.

SIGURJÓNSSON, J., and G. A. VÍKINGSSON. 1997. Estimation of food consumption by cetaceans in Icelandic and adjacent waters. J. Northw. Atl. Fish. Sci., 22: 271-287 (this volume).

SLIJPER, E. J., 1979. Whales, 2nd edition. Hutchinson \& Co. Ltd., London, $511 \mathrm{p}$.

STONE, G. S., S. K. KATONA, A. MAINWARING, J. M. ALLEN, and H. D. CORBETT. 1992. Respiration and surfacing rates of fin whales (Balaenoptera physalus) observed from a lighthouse tower. Rep. Int. Whal. Comm., 42: 739-745.

TARPLEY, R. J., R. F. SIS, T. F. ALBERT, L. M. DALTON, and J. C. GEORGE. 1987. Observations on the anatomy of the stomach and duodenum of the bowhead whale, Balaena mysticetus. Am. J. of Anat., 180: 295-322.

TOMILIN, 1967. Mammals of the USSR and adjacent countries. Vol. 9. Cetacea. Translated from Russian. Israel program for scientific translations. Jerusalem 1967. $717 \mathrm{p}$.

VÍKINGSSON, G. A. 1990. Energetic studies on fin and sei whales caught off Iceland. Rep. Int. Whal. Comm., 40: 365-373.

VÍKINGSSON, G. A. 1995. Body condition of fin whales during summer off Iceland. In: Whales, seals, fish and man, A. Schytte Blix, L. Wallöe, and Ö. Ulltang (eds.). Elsevier Science B.V., p. 361-369.

VÍKINGSSON, G., J. SIGURJÓNSSON, and Th. GUNNLAUGSSON. 1988. On the relationoship between weight, length and girth dimensions in fin and sei whales caught off Iceland. Rep. Int. Whal. Comm., 38: 323-326.

WATKINS, W. A., K. E. MOORE, D. WARTZOK, and J. H. JOHNSON. 1981. Radio tracking of finback (Balaenoptera physalus) and humpback (Megaptera novaeangliae) whales in Prince William Sound, Alaska. Deep-Sea Res., 28: 577-588.

WATKINS, W. A., K. M. MOORE, J. SIGURJÓNSSON, D. WARTZOK, and G. N. SCIARA. 1984. Fin whale (Balaenoptera physalus) tracked by radio in the Irminger Sea. Rit Fiskideildar, 8(1): 1-14. 